\title{
Breeding of a Non-Obese, Diabetic Strain of Mice
}

\author{
Susumu MAKINO, Kikuko KUNIMOTO, Yoshihiro MURAOKA, Yukio MIZUSHIMA, \\ Ken KATAGIRI, and Yoshihiro TOCHINO* \\ Aburahi Laboratories, Shionogi \& Co., Ltd., Gotanda, Kōka-chō, Kōka-gun, Shiga, 520-34 \\ and *Shionogi Research Laboratory, Shionogi \& Co., Ltd., \\ Sagisu, Fukushima-ku, Osaka, 553
}

(Received for publication: April 9, 1979)

\begin{abstract}
A female mouse spontaneously exhibiting polyuria and glucosuria accompanied by rapid weight loss was found in one of two sublines derived from the CTS mice. Eight mating pairs were made using its offspring and selection was performed for both spontaneous diabetes and reproductive ability. After six generations of the selective breeding the diabetic (nod) and the control (non) lines were established.

A marked sex difference was observed in the incidence of diabetic symptoms in the nod mouse. The cumulative incidence of the onset up to 30 weeks of age was $80 \%$ in females and less than $20 \%$ in males. The onset of diabetes was abrupt in both sexes, and spontaneous remission was not observed. However, daily administration of insulin induced an increase of body weight and a prolongation of life span.

Diabetic symptoms are biochemically characterized by polyuria, polydipsia, hyperglycemia, glucosuria and hypercholesteremia. Pathological examination revealed a high frequency of lymphocyte infiltration around and/or into the Langerhans' islet. It was observed even at the prediabetic stage over five weeks of both sexes. The number and size of the islets were markedly reduced in the overt diabetic mice.

Although the mechanism of the pathogenesis is not clear yet, the nod mouse may be a useful animal model for investigating the human juvenile type diabetes.
\end{abstract}

Many hereditary diabetic strains of mice are summerized by Renold [25] and Hunt et al. [13]. All of them are characterized by spontaneous hyperglycemia, hyperinsulinemia and obesity. These mice are valuable for the research of maturityonset type diabetes in man. However no suitable mouse model for the insulin-dependent juvenile type diabetes had been reported, except for the diabetes induced with EMC virus [6] and chemicals such as alloxan.

A female mouse which exhibited polyuria and glucosuria accompanied by weight loss was found during our routine breeding work. This mouse died within a month following rapid deterioration. These features were so interesting that an attempt was made to establish a non-obese diabetic strain. The present paper reports the process of the selective breeding and the characteristics of the diabetic mice.

\section{Materials and Methods}

Animals : Two sublines were separated from the CTS strain [22] at the 6th generation and temporarily named $\mathrm{A}$ and $\mathrm{B}$, 
respectively. The CTS mouse was derived from the JCL-ICR mice and characterized by cataract eyes with microphthalmia [21]. However, both A and B sublines had normal eyes. In 1974, a female mouse showing spontaneous diabetic symptoms was discovered in the A line at the 20th generation. This female mouse had given birth to two litters before showing the diabetic symptoms. As the initial matings for the selective breeding of a diabetic line, five matings between these two litters and three matings between the mice of subline $B$ were performed. The offspring whose one or both parents showed spontaneous diabetes and high reproductivity were selected for breeding. The total number of mice used in the present study was ca. 1500. The check for diabetes was done using Tes-Tape ${ }^{\circledR}$ (Eli-Lilly) as described below.

The animals were maintained under conventional conditions at constant temperature $\left(22-25^{\circ} \mathrm{C}\right)$ until the 4 th or 5 th generation, and thereafter, the pups were placed under aseptic conditions by Caesarean section and fostered by SPF-ICR mothers. Under the conventional conditions, the mice were fed on commercial diet CA-1 (Clea Japan, Inc.) and tap water was available ad libitum. Under the barrier-sustained conditions, the same diet was given after having been autoclaved at $121^{\circ} \mathrm{C}$ for $7 \mathrm{~min}$ and the drinking water at $121^{\circ} \mathrm{C}$ for $35 \mathrm{~min}$.

Laboratory tests: Non-fasting blood samples were obtained with a heparinized syringe by heart puncture under light ether anesthesia, and the plasma was separated quickly at $4^{\circ} \mathrm{C}$ and kept at $-20^{\circ} \mathrm{C}$ until analysis. The plasma glucose level was determined with a Technicon Auto Analyzer, and the plasma cholesterol by the method of Zak-Henly $[12,30]$.

The test for detecting urinary glucose was done directly using Tes-Tape ${ }^{\circledR}$ (EliLilly). This method was used as the criterion for the selective breeding. Animals which showed Tes-Tape values of $1+$ or higher were classified as diabetic. Urinary glucose concentrations were also quantitatively determined by the glucose oxidase method (Glucostat, Worthingtion) on 24hour urine samples. These samples were collected by placing the mice in polycarbonate metabolic cages with toluene as a preservative. For determination of ketonuria, Lab-Stix ${ }^{\mathbb{R}}$ (Ames) was used.

At autopsy, the pancreas was removed and fixed in Bouin's solution. The specimens were dehydrated, embedded in Tissue $\operatorname{Prep}{ }^{\circledR}$, then stained with hematoxylin eosin or Gomoris' aldehyde fuchsin. Histological observation of the liver, kidney, heart, hypophysis, adrenal glands, testes and ovaries was performed by hematoxylin eosin staining after fixing in a $10 \%$ formalin solution.

\section{Results}

\section{Process of selective breeding}

The course of selective breeding is outlined in Fig. 1. Among the initial eight pairs, five females (Nos. $3,4,25,26$, and 27 ) and two males (Nos. 3 and 31) exhibited diabetic symptoms. All of them belonged to the A line. Eighteen litters consisting of 66 females and 72 males were obtained from the initial matings. Of these $\mathrm{F} 1$ mice, 12 females and 3 males were diabetics. The offspring from the three females (Nos. 28, 29 , and 117) which showed good reproductive performance were selected for next brother-sister matings and the process was repeated. The diabetic and non-diabetic lines were clearly separated at the second generation. In the subsequent generations, the three diabetic lines kept showing the same diabetic symptoms.

Caesarean operation was performed in each line, and the pups were carried into the barrier-sustained room to be maintained under SPF conditions. The onset and the syndrome of diabetes under the SPF conditions were almost the same as those observed under the conventional conditions. 


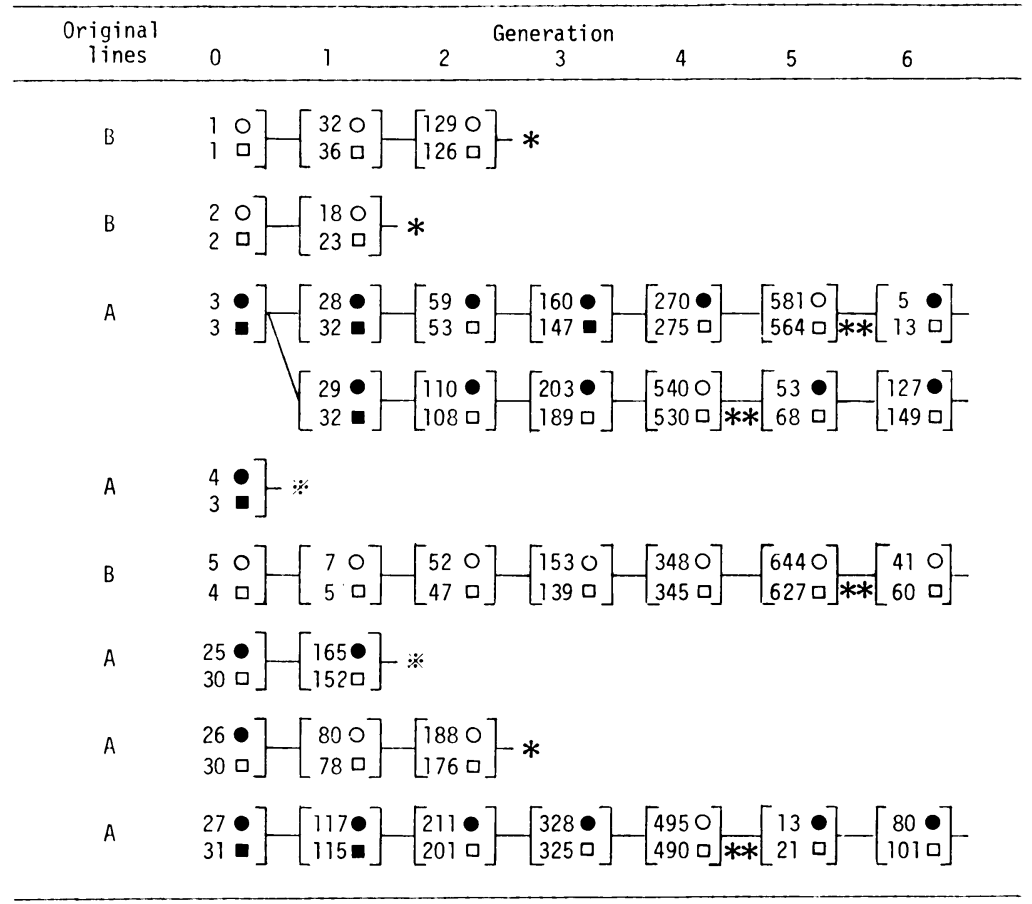

Fig. 1. The pedigree of the diabetic and non-diabetic lines.

The upper and lower numbers in the brackets show the individual numbers of female and male, respectively. Male and female mice were numbered separately.

: Diabetic female. $\bigcirc$ : Normal female. $\square$ : Diabetic male.

: Normal male. $*$ : Discontinued. $* *$ : Caesarean operation. $※$ : Sterile.

Table 1. Changes in diabetic condition accompanied with progress of generation

\begin{tabular}{|c|c|c|c|c|c|c|c|c|}
\hline \multirow{2}{*}{ Item } & \multirow{2}{*}{ Sex } & \multicolumn{7}{|c|}{ Generation } \\
\hline & & 0 & 1 & 2 & 3 & 4 & 5 & 6 \\
\hline \multirow{2}{*}{$\begin{array}{l}\text { Incidence of } \\
\text { diabetes }(\%)\end{array}$} & 우 & 62.5 & 84.6 (13) & $83.3(24)$ & $51.7(29)$ & $73.7(19)$ & $67.4(43)$ & 61.8 \\
\hline & $\hat{\delta}$ & $33.3(6)$ & $33.3(9)$ & $6.7(15)$ & 7.1 (14) & $10.5(19)$ & $9.5(21)$ & $0(25)$ \\
\hline \multirow{2}{*}{$\begin{array}{l}\text { Age at onset } \\
\text { (days) }\end{array}$} & 우 & $194(2)$ & $172(10)$ & $179(19)$ & 179 (14) & 149 (12) & $147(25)$ & 139 (21) \\
\hline & $\hat{\delta}$ & $246(2)$ & $312(3)$ & 276 & $248(1)$ & $168(1)$ & $177(2)$ & $\cdots$ \\
\hline \multirow{2}{*}{$\begin{array}{l}\text { Time from } \\
\text { onset to death } \\
\text { (days) }\end{array}$} & 우 & $52(2)$ & $36(9)$ & $45(17)$ & $41(12)$ & $44(10)$ & $27(5)$ & $24(5)$ \\
\hline & $\hat{\delta}$ & $61(2)$ & & - & 135 & - & $43(1)$ & $\ldots$ \\
\hline
\end{tabular}

Each value shows the mean calculated from the breeding record of the mice that survived beyond 150 days of age.

( ) : No. of mice examined.

- No data were available.

The incidence, age at onset and duration of diabetes in each generation in the course of selective breeding are shown in Table 1. These data were taken from the breeding record of the mice that survived beyond 150 days of age. The incidence in females was constant up to the 6 th generation, being about 60 to $80 \%$. In contrast, 
the incidence in males decreased with the progress of generations. Namely, the incidence was $33.3 \%$ in the first two generations, but became less than $10 \%$ after the second generation.

The onset of overt diabetes in female mice was around the age of 200 days at the early stage of selection, but tended to occur about 50 days earlier after the fourth generation. The onset was late in males compared with the females, and took more than 200 days during the first four generations. After the fourth generation, the age of onset shortened as the females. The survival time after the onset was very short in both sexes. In females, the survival time was more than 40 days in early generations, but later shortened to about 25 days.

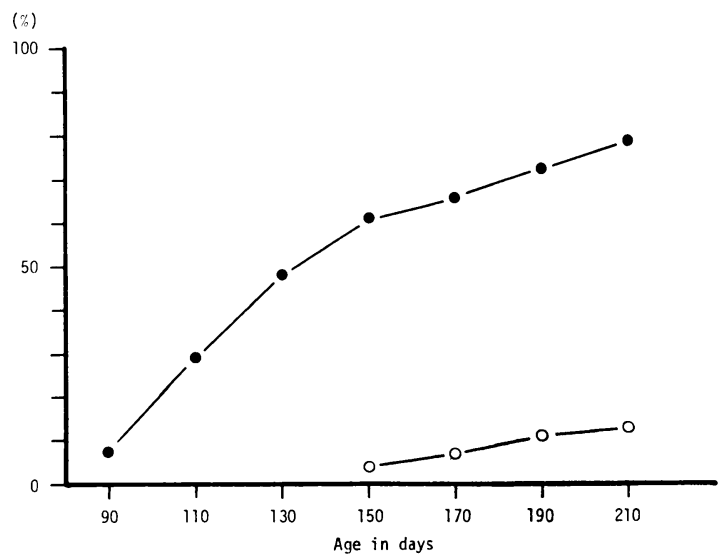

Fig. 2. Cumulative incidences of the diabetic mice.

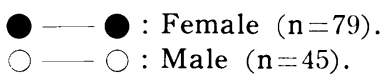

2. Clinical symptoms

Table 2. Clinical characteristics and biochemical values in the diabetic mice before onset of diabetes

\begin{tabular}{|c|c|c|c|c|c|}
\hline $\begin{array}{l}\text { Age in } \\
\text { weeks }\end{array}$ & Sex & $\begin{array}{c}\text { Body weight } \\
(\mathrm{g})\end{array}$ & $\begin{array}{l}\text { Water intake } \\
(\mathrm{ml} / \text { day })\end{array}$ & $\begin{array}{l}\text { Urine volume } \\
(\mathrm{ml} / \text { day })\end{array}$ & $\begin{array}{l}\text { Food consumption } \\
\qquad(\mathrm{g} / \text { day })\end{array}$ \\
\hline \multirow{2}{*}{5} & 우 & $20.1 \pm 1.3(75)$ & $5.0 \pm 1.0$ & $0.8 \pm 0.4(75)$ & $3.3 \pm 0.6(71)$ \\
\hline & $\hat{\delta}$ & $24.8 \pm 1.8(54)$ & $5.9 \pm 1.2(54)$ & $1.0 \pm 0.5$ & $3.9 \pm 0.5(50)$ \\
\hline \multirow{2}{*}{9} & 우 & $21.9 \pm 1.9(11)$ & $5.1 \pm 1.2(11)$ & $1.1 \pm 0.8$ & $3.2 \pm 0.4(7)$ \\
\hline & $\hat{\delta}$ & $28.8 \pm 1.5(10)$ & $4.7 \pm 0.7(10)$ & $0.8 \pm 0.3(10)$ & $3.5 \pm 0.6(6)$ \\
\hline \multirow{2}{*}{17} & 우 & $25.2 \pm 1.6(15)$ & $5.4 \pm 1.4(15)$ & $1.2 \pm 1.4(15)$ & $3.3 \pm 0.5(6)$ \\
\hline & $\hat{\sigma}$ & $32.7 \pm 1.6(16)$ & $5.7 \pm 1.4(16)$ & $0.9 \pm 0.4(16)$ & $4.0 \pm 1.5(5)$ \\
\hline $\begin{array}{l}\text { Age in } \\
\text { weeks }\end{array}$ & Sex & $\begin{array}{l}\text { Plasma glucose } \\
\qquad \mathrm{mg} / \mathrm{dl})\end{array}$ & $\begin{array}{l}\text { Urinary glucose } \\
\qquad(\mathrm{mg} / \mathrm{dl})\end{array}$ & $\begin{array}{l}\text { Plasma cholesterol } \\
(\mathrm{mg} / \mathrm{dl})\end{array}$ & $\begin{array}{l}\text { Ketonuria* } \\
(\text { positive } \%)\end{array}$ \\
\hline \multirow{2}{*}{5} & 우 & $190.8 \pm 33.4$ & $22.4 \pm 28.3(75)$ & $76.1 \pm 9.3(10)$ & $0(4)$ \\
\hline & $\hat{o}$ & $187.1 \pm 41.2$ & $12.9 \pm 20.3$ & $103.0 \pm 10.0(9)$ & $0(4)$ \\
\hline \multirow{2}{*}{9} & 우 & $163.7 \pm 34.6$ & $182.5 \pm 147.7(4)$ & $126.7 \pm 31.6(25)$ & $0(4)$ \\
\hline & $\hat{o}$ & $171.5 \pm 41.5$ & $72.5 \pm \quad 5.0$ & $140.6 \pm 28.5$ & $0(4)$ \\
\hline \multirow{2}{*}{17} & 우 & $225.7 \pm 63.8(9)$ & $115.0 \pm 85.1$ & $78.6 \pm 0.2(3)$ & $0(4)$ \\
\hline & $\hat{\delta}$ & $163.0 \pm 22.6(9)$ & $53.4 \pm 102.1(9)$ & $106.6 \pm 0.2(8)$ & $0(4)$ \\
\hline
\end{tabular}

Each value represents the mean \pm standard deviation.

( ) : No. of mice examined.

* : Ketonuria was determined using Lab-Stix (Ames).

In order to investigate the time course of the onset and progress of diabetes, the diabetic mice were inspected with Tes-
Tape once a week from 13 to 30 weeks of age. As shown in Fig. 2, overt diabetic symptoms in the females were first ob- 
Table 3. Clinical characteristics and biochemical values in the diabetic mice after onset of diabetes

\begin{tabular}{|c|c|c|c|c|c|}
\hline $\begin{array}{l}\text { After onset } \\
\text { (weeks) }\end{array}$ & Sex & $\begin{array}{l}\text { Body weight } \\
\text { (g) }\end{array}$ & $\begin{array}{l}\text { Water intake } \\
(\mathrm{ml} / \text { day })\end{array}$ & $\begin{array}{l}\text { Urine volume } \\
(\mathrm{ml} / \text { day })\end{array}$ & $\begin{array}{l}\text { Food consumption } \\
\qquad(\mathrm{g} / \text { day })\end{array}$ \\
\hline \multirow[b]{2}{*}{$0-2$} & 우 & $28.1 \pm 4.4(18)$ & $22.6 \pm 6.9(14)$ & $17.0 \pm 5.9$ (14) & $4.8 \pm 1.2(14)$ \\
\hline & $\hat{\delta}$ & $29.9 \pm 2.5(3)$ & $21.6 \pm 9.3(2)$ & $14.8 \pm 7.1(2)$ & $4.8 \pm 1.5(3)$ \\
\hline \multirow[b]{2}{*}{$2-4$} & 우 & $25.8 \pm 4.6(28)$ & $26.4 \pm 4.8(22)$ & $19.8 \pm 4.3(19)$ & $6.1 \pm 1.6(19)$ \\
\hline & $\hat{\delta}$ & $17.7 \quad$ (1) & $21.4 \quad$ (1) & $19.3 \quad$ (1) & $4.7 \quad$ (1) \\
\hline \multirow[b]{2}{*}{$>4$} & 우 & $24.6 \pm 3.7(21)$ & $26.3 \pm 6.1(9)$ & $18.4 \pm 4.7(5)$ & $5.0 \pm 1.4(5)$ \\
\hline & $\hat{\delta}$ & $26.6 \pm 3.9$ (12) & $23.2 \pm 6.5$ & $17.9 \pm 6.8(8)$ & $5.1 \pm 1.2(9)$ \\
\hline $\begin{array}{l}\text { After onset } \\
\text { (weeks) }\end{array}$ & Sex & $\begin{array}{c}\text { Plasma glucose } \\
(\mathrm{mg} / \mathrm{dl})\end{array}$ & $\begin{array}{l}\text { Urinary glucose } \\
(\mathrm{mg} / \mathrm{dl})\end{array}$ & $\begin{array}{l}\text { Plasma cholesterol } \\
\qquad(\mathrm{mg} / \mathrm{dl})\end{array}$ & $\begin{array}{l}\text { Ketonuria* } \\
\left(\text { positive }^{0}, 0\right)\end{array}$ \\
\hline \multirow{2}{*}{$0-2$} & 우 & $644.9 \pm 140.5(6)$ & $13.8 \pm 4.9(12)$ & $162.2 \pm 63.7(6)$ & $16.7(12)$ \\
\hline & $\hat{\delta}$ & 239.4 & $12.7 \pm 4.0$ & & $0(3)$ \\
\hline \multirow{2}{*}{$2-4$} & 우 & $730.7 \pm 166.7$ & $12.3 \pm 5.3(18)$ & $601.1 \pm 304.2(12)$ & 26.7 (15) \\
\hline & $\hat{\jmath}$ & 666.6 & $9.6 \quad(1)$ & - & $0(1)$ \\
\hline \multirow{2}{*}{$>4$} & 우 & $714.2 \pm 260.2(10)$ & $10.1 \pm 6.3(9)$ & $836.4 \pm 185.4$ & $66.7(6)$ \\
\hline & $\hat{\delta}$ & $597.5 \pm 186.4(6)$ & $10.5 \pm 5.7(8)$ & 1902 & $0(10)$ \\
\hline
\end{tabular}

served at the age of 90 days, and the occurrence of diabetes showed a steady rise with age. The incidences of diabetes up to 130 days and 210 days were about $50 \%$ and $80 \%$, respectively. No significant difference was observed in the incidence of diabetes between the multiparous and virgin females.

On the other hand, the onset occurred in males 60 days later than in females. The cumulative incidence of the diabetes up to 210 days was very low, not exceeding $20 \%$. Thus, significant sex differences were confirmed with respect to the frequency and the time of the onset.

The clinical characteristics and biochemical parameters of the diabetic mice before and after onset of diabetes are shown in Tables 2 and 3. Daily water consumption and urine excretion prior to onset were within the normal range, regardless of sex or age. However, marked polydipsia and polyuria developed after onset. Water intake increased about four times and urine excretion 15-20 times. The overt diabetic mice after onset also showed a tendency toward polyphagia.

Plasma glucose concentrations ranged from 163.7 to $225.7 \mathrm{mg} / \mathrm{dl}$ prior to onset of diabetes. With onset of glucosuria, plasma glucose levels rose about three-fold and urinary glucose concentrations about a hundred-fold. Plasma cholesterol levels also increased significantly and ketonuria was observed frequently in the overt diabetic females.

Conspicuous weight loss was associated with the abrupt onset of diabetes in both sexes as illustrated in Fig. 3. The decline of body weight was more remarkable in females than in males. The mice at the onset of diabetes weighed more than $30 \mathrm{~g}$, but less than $20 \mathrm{~g}$ before the death. All of the diabetic females continuously ex- 


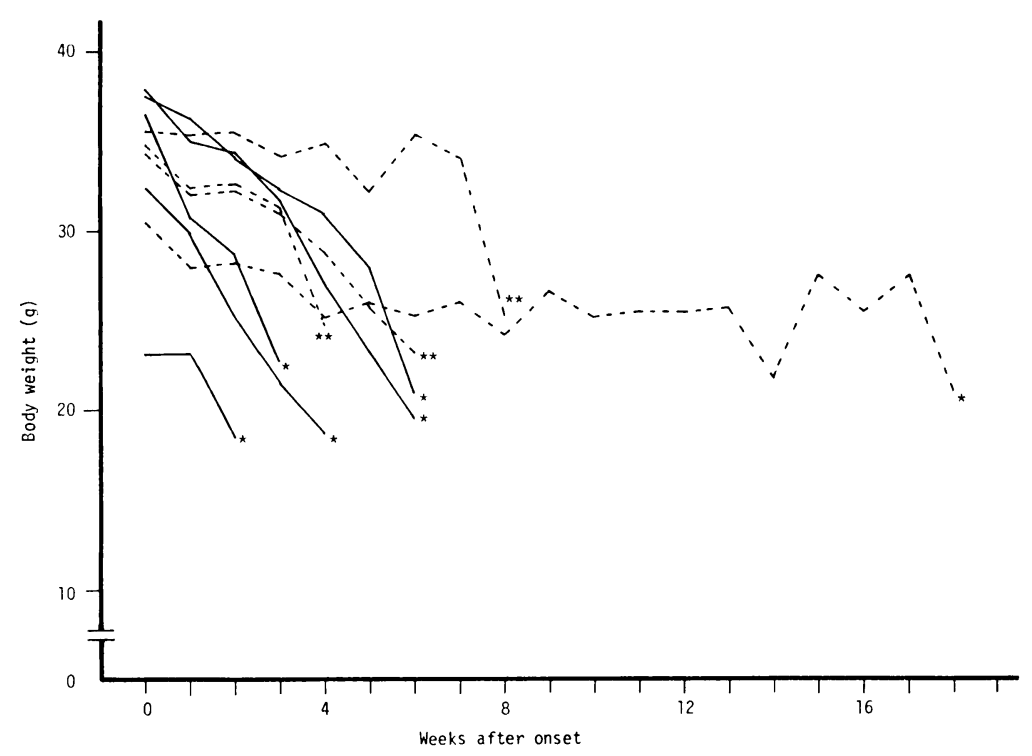

Fig. 3. Changes in body weight after the onset of diabetes.

: Female. -_-_: Male. *: Dead. **: Autopsy.

creted large amounts of glucose in the urine. In males, however, negative glucosuria was occasionally observed after the onset. No spontaneous remission from diabetes was observed.

The response of the diabetic mice to exogenous insulin was examined. Insulin was given subcutaneouly at a dose of 40 units per $\mathrm{kg}$ of body weight per day in the evening; the dose being comparable to that necessary for survival in alloxan-induced diabetic mice. Daily injection of insulin induced an increase of body weight and a marked prolongation of life span in diabetic mice (Fig. 4). One female mouse with severe symptoms (No. 59) showed a remarkable restoration of body weight with a temporal recovery to $30 \mathrm{~g}$. When the insulin injection was stopped, the body weight decreased again. All the diabetic mice survived during the insulin treatment. These results suggested that the diabetic mice might be suffering from an insulin deficiency.

The reproductive capacities between diabetic and non-diabetic lines are compared in Table 4. The parturition rate of the diabetic line was $39.0 \%$, considerably

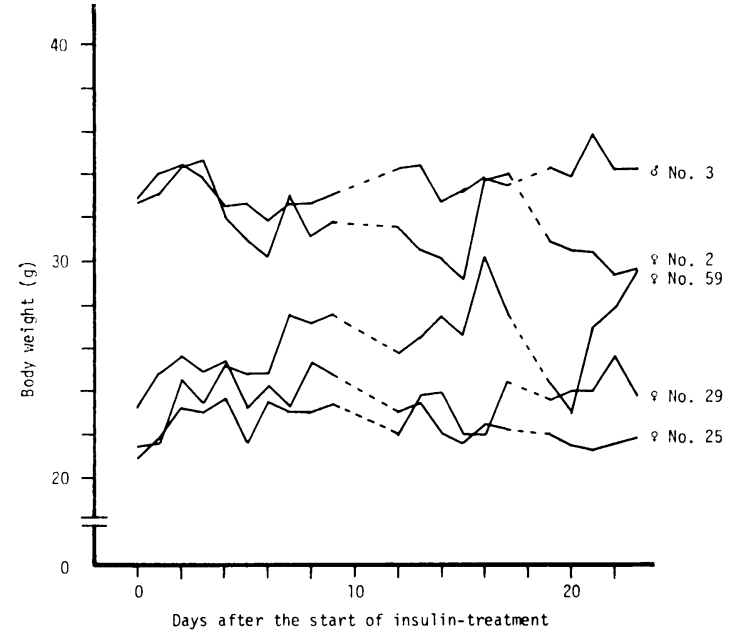

Fig. 4. Effect of the daily insulin treatment $(40 \mathrm{U} / \mathrm{kg}, \mathrm{sc})$ on the body weight of the diabetic mice.

The broken lines show the change in body weight when the treatment was stopped.

lower than that of the non-diabetic line. Though many of these diabetic mice were infertile during this experiment, they of ten became pregnant in subsequent matings. This evidence suggests that long-term mating is neccessary for reproduction in the 
Table 4. Reproductive performance of the diabetic and non-diabetic lines

\begin{tabular}{lcrc}
\hline \multicolumn{1}{c}{ Line } & $\begin{array}{c}\text { Parturition rate* } \\
(\%)\end{array}$ & Litter size & $\begin{array}{c}\text { Weaning rate } \\
(\%)\end{array}$ \\
\hline Non-diabetic & $82.4(17)$ & $9.4 \pm 1.0(14)$ & $100.0(115)$ \\
Diabetic & $39.0(41)$ & $10.1 \pm 1.7(15)$ & $100.0(129)$ \\
\hline
\end{tabular}

The period of mating was 2 weeks.

( ) : No. of mice examined.

* : No. of delivery females/No. of females mated.

diabetic line. Most of the mothers before the onset of diabetes could nurse their pups well (Table 4). However, most of mothers showing overt diabetes could not complete weaning their pups due to their short life.

Other abnormalities such as abdominal distention and spinal curvature were observed following the onset of diabetes. Some mice became soiled with urine, and their fur became damp and yellowish. At the terminal stage, the animals showed wasting syndromes and finally entered a comatose state and died. The autopsy findings of the diabetic mice revealed atrophy of the thymus and spleen and dilatation of the intestines, gall bladder, and cecum. Elongation of the intestines was also observed. Cataract eyes were noted only in one diabetic mouse.

3. Histological findings

Light-microscopic observations were carried out on the pre-diabetics and the diabetics. Several morphologic alterations of the Langerhans' islets had occurred not only in the diabetics but also in the prediabetics over five weeks of age. In the pancreases of the pre-diabetics, the most prominent findings were infiltration of periand intra-insular mononuclear cells, mainly lymphocytes. The cellular infiltration was also observed around the peri-ductal and peri-vascular structures (Photo 2). At the more advanced state, most of the original cells constituting the islets decreased in number and were entirely replaced by the lymphocytes (Photo 3 ). The inflammatory reaction generally showed a tendency to disappear at the terminal stage of the prediabetes (Photo 4). A morphologic picture of a overt diabetic mouse is shown in Photo 5. The pancreatic islet was exceedingly shrunken and small in size as compared with a normal islet (Photo 1). The decrease in the number of islets was also significant. In some cases, lymphocyte infiltration disappeared (Photo 5). These islets were characterized by the absence of aldehyde fuchsin positive cells (Photo 8). In contrast, many beta cells with well preserved aldehyde fuchsin positive granules were seen in the pancreatic islets of the pre-diabetic mouse (Photo 7). The incidence of cellular infiltration at the age of five weeks was $82.0 \%$ in females and $57.5 \%$ in males, respectively (data not shown). Sex difference was not remarkable for the spontaneous occurrence of cellular infiltration. In some cases, lymph node formation was observed around the pancreatic tissue or adjacent to the pancreatic lobules; however, the exocrine glands of the pancreases showed no remarkable changes in both the diabetic and pre-diabetic stages.

Apart from the pancreas, peri-vascular aggregations of the lymphocytes in the kidney and liver were observed occasionally, but similar changes were also noted in some of the non-diabetic control. Most of the other organs, including the heart, brain, spleen, adrenal glands, hypophysis, testes, and ovaries, appeared to be normal.

\section{Discussion}

The present report has shown the 
breeding of non-obese type diabetic strain of mice. The incidence of diabetes was constant throughout six generations of selective breeding, being approximately 60 to $80 \%$ in females and about $10 \%$ in males around the age of 150 days or older. The control line was simultaneously bred from a sister strain. We called these lines "nonobese diabetic : nod" mouse and "non-obese normal : non" mouse.

The characteristic features of this diabetic mouse are:(1) abrupt onset of symptoms with polyuria, polydipsia, glucosuria and hyperglycemia accompanied by rapid weight loss, (2) infiltration of lymphocytes into the islets and conspicuous reduction in the number of beta cells and the size of islets, and (3) insulin deficiency [28]. Recently, Nakhood et al. [19, 20] reported on spontaneous diabetic rats not associated with obesity. Although they did not establish a strain of diabetic rat, the clinical symptoms and pathological findings of the pancreas were almost the same as our results. These characteristics are similar to those of human diabetes of the juvenile-onset type.

Pancreatic insulitis has been reported by Gepts [10] in juvenile diabetes of patients autopsied shortly after the onset of clinical symptoms. Such a histological change has also been demonstrated recently in streptozotocin-induced diabetic mice [17] and previously in Wistar rats with spontaneous diabetes $[19,20]$. Two hypotheses can be proposed concerning the pathogenesis of insulitis, i. e., viral infection and immunological impairment. There is much evidence suggesting a relationship between viral infection and the onset of diabetes, particularly of insulin-dependent juvenileonset type diabetes $[5,9,18,24,26]$. Coxsackie $B$ virus $[8,9,29]$, mumps virus [27] and Reovirus [23] have been assumed to be responsible for the etiology of diabetes, though the participation of viruses is still inconclusive except for EMC virus $[2,3,4]$ in mice. EMC virus can definitely produce diabetes characterized by hyperglycemia, hypoinsulinemia, glucosuria, polydipsia, beta cell destruction, and insulitis in the islets of pancreas $[2,4,11]$. The symptoms observed in this report resemble those of diabetes induced with EMC virus in many respects except the following : (1) low incidence of onset in males $[2,7]$, (2) progressive weight loss [2], (3) 100\% mortality [2], and (4) the absence of extensive myocardial necrosis [3].

Recently, the possibility of the presence of an infectious agent in the development of spontaneous diabetes in guinea pigs was suggested by Lang and Munger $[15,16]$. Although an infectious agent has not yet been isolated, they regard this disease as contagious because healthy guinea pigs introduced into the colony of the diabetic animals develop similar syndromes. During the course of the present study, however, no diabetic symptoms were observed in the $\mathrm{DBA} / 2, \mathrm{C} 57 \mathrm{BL}, \mathrm{C} 3 \mathrm{H}$ mice or the other few inbred strains which were kept in the vicinity of the diabetic mice.

Another possible mechanism for the onset of diabetes is pathogenesis through some immunological events. The following four types of experimental immune insulitis are known (Kawanishi et al. [14], and Basterie [1]) : (1) insulitis by active immunity to insulin like that which develops in cattles immunized with homologous or heterologous insulin mixed with Freund's adjuvant, (2) insulitis by passive immunity as seen in mice and rats injected with anti-bovine or anti-porcine insulin serum of guinea pigs, (3) insulitis due to immunity to pancreas-specific tissue and antigens as produced in mice and rats immunized with pancreas extract, and (4) insulitis due to deposition of immune complexes in the islets which are formed by the combination of some viruses with high affinity to pancreas and antibodies. The last mechanism is most likely responsible for spontaneous diabetes in nod mice.

A conspicuous sex difference was observed in the spontaneous onset of diabetes. 
Such a difference, however, was not seen for the incidence of pancreatic insulitis. Consequently, we can speculate that the androgenic hormone represses the spontaneous onset of the disease in males. Whether the sex hormones play a role or not is presently under investigation and analysis of the pathogenesis of the nod mouse from genetical, immunological and ultrastructural standpoints is also in progress.

\section{References}

[1] Bastenie, P. A. (1973). Immunity, autoimmunity, and diabetes. In diabetes; proceedings of the eighth congress of the international diabetes federation, Brussels. Mallaisse, W. J., and Pirart, J., editors, Excerpta Medica, Amsterdam, 3-21.

[2] Boucher, D. W., and Notkins, A. L. (1973). Virusinduced diabetes mellitus. I. Hyperglycemia and hypoinsulinemia in mice infected with encephalo. myocarditis virus. J. Exp. Med., 137, 1226-1239.

[3] Craighead, J. E. (1966). Pathogenicity of the M and E variants of the encephalomyocarditis (EMC) virus. Amer. J. Path., 48, 375-386.

[4] Craighead, J. E., and Steinke, J. (1971). Diabetes mellitus-like syndrome in mice infected with encephalomyocarditis virus. Am. J. Path., 63, 119-134.

[5] Craighead, J. E. (1972). Workshop on viral infection and diabetes mellitus in man. J. Infect. Dis., 125, 568-570.

[6] Craighead, J. E. (1975). Animal model of human disease. Diabetes mellitus. Am. J. Path., 78, 537-540.

[7] Friedman, S. B., Grota, L. J., and Glasgow, L. A. (1972). Differential susceptibility of male and female mice to encephalomyocarditis virus : Effects of castration, adrenalectomy, and the administration of sex hormones. Infect. Immun., 5, 637-644.

[8] Gamble, D. R., Kinsley, M. L., FitzGerald, M. G., Bolton, R., and Taylor, K. W. (1969). Viral antibo. dies in diabetes mellitus. Brit. Med. J., 3, 627-630.

[9] Gamble, D. R., Coleman, T. J., and Taylor, K. W. (1973). Epidemiological and experimental studies in relation to Coxsackie viruses as an aetiological factor in diabetes. In diabetes; proceedings of the eighth congress of the international diabetes federation, Brussels. Mallaisse, W. J., and Pirart, J., editors, Excerpta Medica, Amsterdam, 321-326.

[10] Gepts, W. (1965). Pathologic anatomy of the pancreas in juvenile diabetes mellitus. Diabetes, 14, 619633.

[11] Hayashi, K., Boucher, W., and Notkins, A. L. (1974). Virus-induced diabetes mellitus. II. Relationship between beta cell damage and hyperglycemia in mice infected with encephalomyocarditis virus. Am. J. Path., 75, 91-102.

[12] Henly, A. A. (1957). The determination of serum cholesterol. Analyst. 82, 286-287.

[13] Hunt, C. E., Lindsey, J. R., and Walkley, S. U.

\section{Acknowledgments}

We wish to thank Prof. K. Kondo of Nagoya University for his constant interest and guidance in this investigation. We are also grateful to Dr. N. Wakasugi of the Nagoya University for careful review of this manuscript and to Dr. M. Harada of the Shionogi Research Laboratory for his valuable suggestions.

(1976). Animal models of diabetes and obesity, including the $\mathrm{PBB} / \mathrm{Ld}$ mouse. Federation Proceed ings, 35, 1206-1217.

[14] Kawanishi, K., and Okada, S. (1976). Experimental immune insulitis. Igaku No Ayumi, 96, 866-870. (In Japanese).

[15] Lang, C. M., and Munger, B. L. (1976). Diabetes mellitus in the guinea pig. Diabetes, 25, 434-443.

[16] Lang, C. M., Munger, B. L., and Rapp, F. (1977). The guinea pig as an animal model of diabetes mellitus. Lab. Anim. Sci., 27, 789-805.

[17] Like, A. A., and Rossini, A. A. (1976). Streptozo. tocin-induced pancreatic insulitis : New model of diabetes mellitus. Science, 193, 415-417.

[18] Maugh, T. H. (1975). Diabetes : Epidemiology suggests a viral connection. Science, 188, 347-351.

[19] Nakhooda, A. F., Like, A. A., Chappel, C. I., Mu. rray, F. T., and Marliss, E. B. (1977). The spontaneously diabetic Wistar rat. Metabolic and morpho. logic studies. Diabetes, 26, 100-112.

[20] Nakhooda, A. F., Like, A. A., Chappel, C. I., Wei, C. N., and Marliss, E. B. (1978). The spontaneously diabetic Wistar rat. Studies prior to and during development of the overt syndrome. Diabetologia, 14, 199-207.

[21] Ohotori, H., Yoshida, T., and Inuta, T. (1968). "Small eye and cataract," a new dominant mutation in the mouse. Exp. Anim., 17, 91-96. (In Japanese with english summary).

[22] Ohotori, H., and Yoshida, T. (1975). The CTS mouse. In reference. Exp. Anim., 24, 123. (In Japanese).

[23] Onodera, T., Jenson, A. B., Yoon, J-W., and Notkins, A. L. (1978). Virus-induced diabetes mellitus : Reovirus infection of pancreatic beta cells in mice. Science, 201, 529-531.

[24] Rayfield, E. J., and Seto, Y. (1978). Viruses and the pathogenesis of diabetes mellitus. Diabetes, 27, 1126-1140.

[25] Renold, A. E. (1968). Spontaneous diabetes and/or obesity in laboratory rodents. Adv. Metab. Disord., 3, 49-84.

[26] Steike, J., Taylor, K. W. (1974). Viruses and the etiology of diabetes. Diabetes, 23, 631-633.

[27] Sultz, H. A., Hart, B. A., Zielezny, M., Schlesinger, E. R. (1975). Is mumps virus an etiologic factor in juvenile diabetes mellitus?. J. Pediatrics, 86, 654656. 
[28] Tochino, Y., Kanaya, T., and Makino, S. (1978). Studies on spontaneously non-obese diabetic mice. The Journal of the Japan Diabetic Society, 21, 295. (In Japanese).

[29] Yoon, J-W., Onodera, T., and Notkins, A. L. (1978). Virus-induced diabetes mellitus. XV. Beta cell damage and insulin-dependent hyperglycemia in mice infected with Coxsackie virus B4. J. Exp. Med., 148, 1068-1080.

[30] Zak, B. (1957). Simple rapid microtechnic for serum total cholesterol. Amer. J. Clin. Path., 27, 583-587.

\title{
ヤセ型糖㽷マウスの育種
}

\author{
牧野進・国本喜久子・村岡 義博 \\ 水島敬夫・片桐亲・椅野義博* \\ 塩野義製薬油日ラボラトリーズ，*塩野義研究所
}

多尿，尿糖強陽性を呈し，急激な衰弱を伴い死亡した 1 匹の继隹マウスがCTS 系マウスの亜系で偶然発見され た。子孫をもとに 8 対の交配系を作成し, 親の糖尿発症 および繁殖力を指標とし，糖尿マウスの選択を試みた。 6 世代にわたる選択により, 糖尿発症系（nod）とその 対照系（non）の 2 系統が育成された。

nod マウスの 顕性糖尿出現には 著明な䊒雄差が認め られ，30週令までの累積発症率は雌で $80 \%$ ，雄で20\%程 度であった。発症は急激に出現し, 発症後は体重減少, 衰弱が急速であった。自然回復する動物はみられず，放 置すると約 1 ～2 月正死した。しかし，インスリン を連続投与することにより，体重增加がみられ，ある程 度寿命を延長させることが可能であった。
病態の生化学的特徴としては, 多尿, 多飲, 高血糖, 尿桾強陽性, 高コレステロール血症がみられた。また， 病理学的特徵としては膵ラ氏島に種々の程度のリンバ球 浸潤が認められた。リンパ球浸潤の出現は，5週令以上 の糖尿発症前期の動物にも高率に認められ，その出現に は糖尿発症でみられたよらな著明な䊒雄差はみられなか った。顕性糖尿マウスの膵ラ氏島はいずれも強い萎縮像 を呈し，島の数ばかりでなく，島を構成する細胞数にも 著減がみられた。

病因については不明であるが，育種された nod マウ スはヒトの若年型インスリン絶対不足糖尿病のモデル動 物としての使用が期待出来るものと考えられる。 

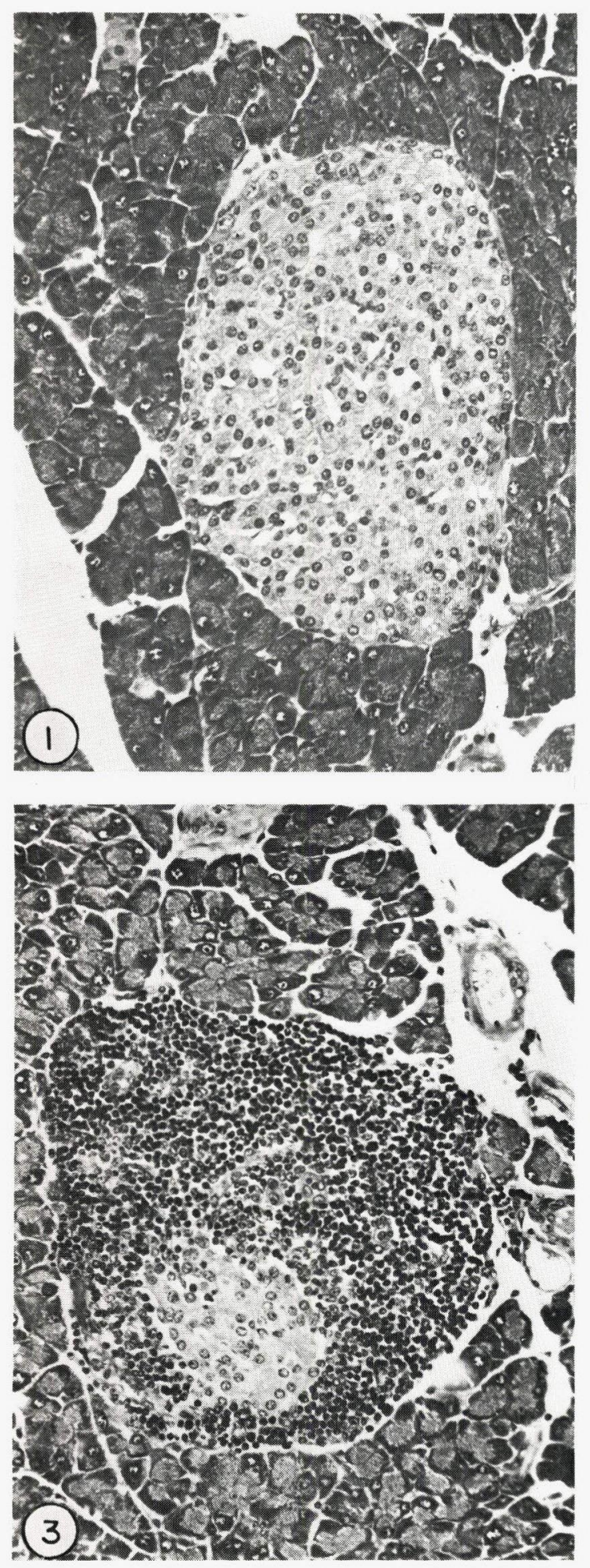
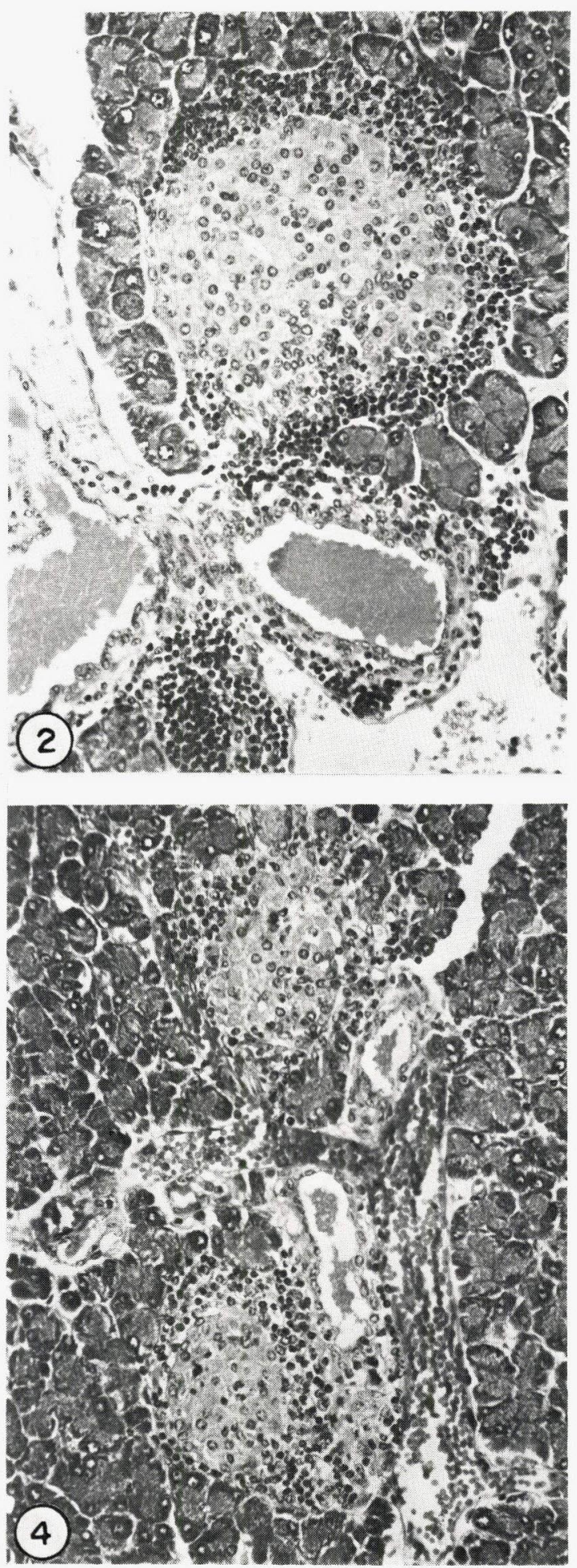

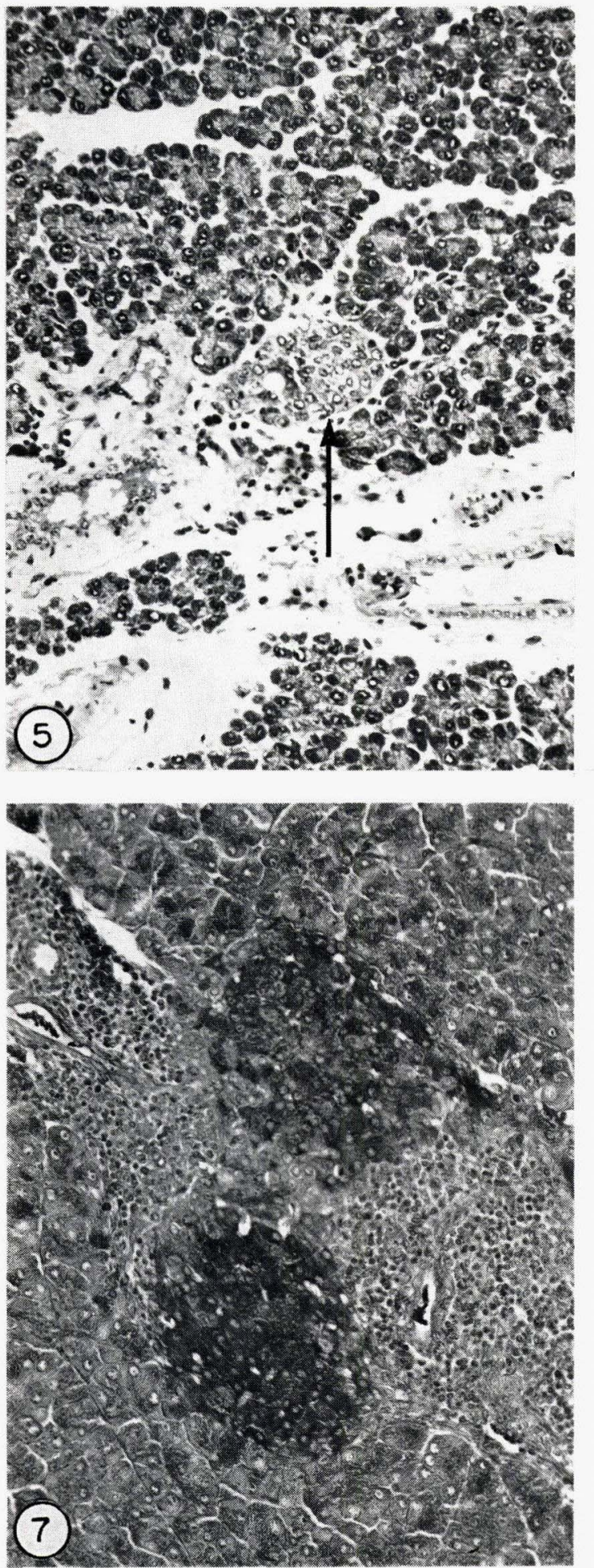
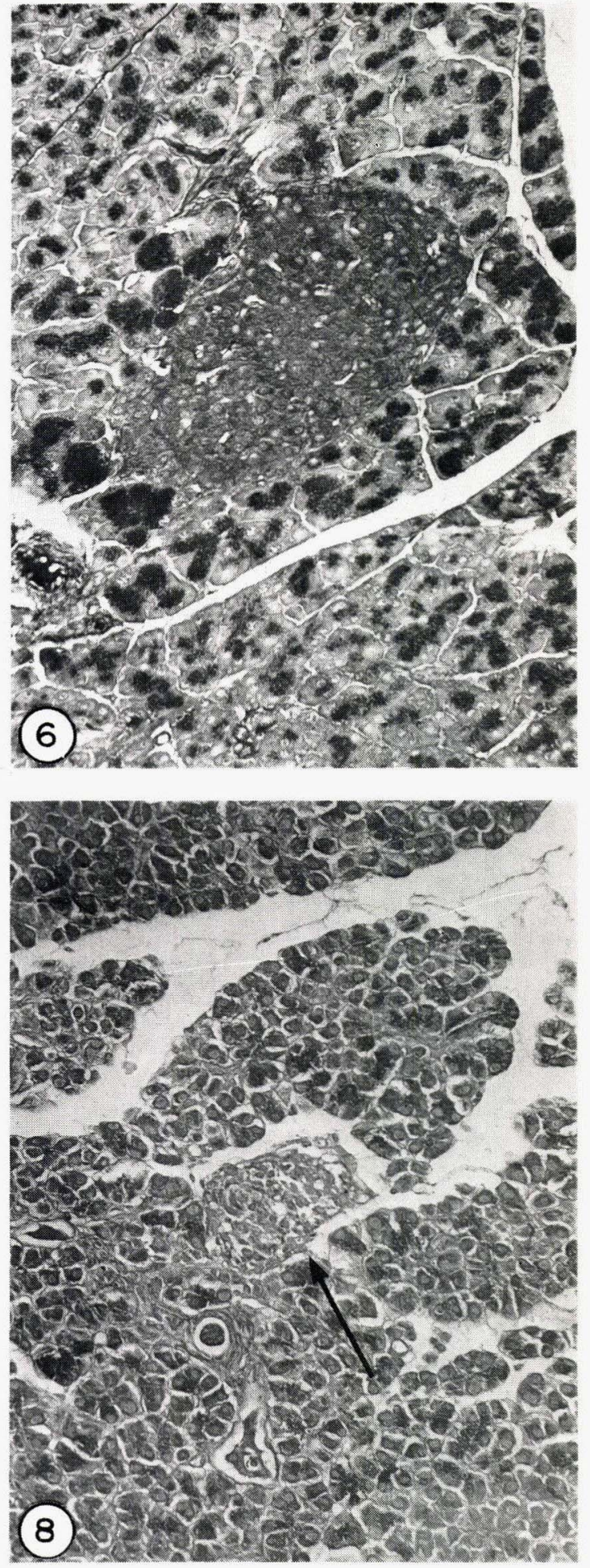


\section{Explanation of Microphotographs}

Photo 1. Pancreatic islet of a normal mouse. H-E. 200x.

Photos 2 to 4 . Pancreatic islets of the diabetic mice in the pre-diabetic stage. Lymphocyte infiltration around the islet and the neig. hboring dilated ductal and vascular structures is visible (Photo 2). When these changes accelerated, most of the cells constituting the islet were entirely replaced by the lymphocytes (Photo 3). Lymphocyte infiltration tended to increase with age, but at the terminal stage of pre-diabetes only a small number of residual lymphocytes was found adjacent to the ductal structures and the islets (Photo 4). H-E. 200x.

Photo 5. Pancreatic islet of a diabetic mouse with hyperglycemia. Compared with a normal islet (Photo 1), the islet (arrow) is exceedingly small in size. Note the disappearance of lymphocyte infiltration around the atrophied islet. H-E. 200x.

Photo 6. Pancreatic islet of a normal mouse. The islet shows wellgranulated beta cells (dark stain). Aldehyde fuchsin. 200x.

Photo 7. Pancreatic islet of a diabetic mouse in the pre-diabetic stage. Most of the residual cells of the islet are aldehyde fuchsin positive (dark stain). Aldehyde fuchsin. $200 \mathrm{x}$.

Photo 8. Another islet (arrow) found in the same pancreas shown in Photo 5. Note the complete absence of aldehyde fuchsin positive cells. Aldehyde fuchsin. 200x. 